\title{
Characterization of Corynebacterium Group JK by Whole-cell Protein Patterns
}

\author{
By P. J. H. JACKMAN*† AND STEPHANIE PELCZYNSKA \\ Department of Bacteriology, Institute of Dermatology, Homerton Grove, London E9 6BX, UK
}

(Received 19 November 1985 ; revised 21 February 1986)

\begin{abstract}
A total of 102 strains received as $\dot{C}$ orynebacterium 'group JK' were characterized by SDS-PAGE of their whole-cell proteins. Numerical taxonomy based on the protein pattern absorbance profiles indicated that 91 of the strains formed a cluster. Seventy strains isolated in the UK were identified as group $\mathrm{JK}$, indicating the increasing detection of this group as opportunistic pathogens. Fine differences between strain patterns were visible but it was not possible to associate these with any particular clinical source.
\end{abstract}

\section{INTRODUCTION}

Corynebacterium spp. are common inhabitants of healthy human skin and mucous membranes. A number of highly antibiotic-resistant coryneform bacteria isolated from serious human infections, typically endocarditis, have been characterized and designated 'group JK' by the Special Bacteriology Section at the Centers for Disease Control (CDC), Atlanta, Ga., USA (Riley et al., 1979). Group JK strains were characterized as catalase-positive, oxidase-negative, fermentative Gram-positive aerobic micro-organisms, which did not reduce nitrate. They were commonly resistant to ampicillin, cephalothin, chloramphenicol, erythromycin, gentamicin, penicillin $G$, streptomycin and tetracycline, and sensitive only to vancomycin.

Comparison of electrophoretic patterns of whole-cell proteins is useful in systematic studies of Corynebacterium (Jackman, 1982), and relationships between protein patterns have generally shown a high correlation with those from DNA-DNA hybridization (Owen \& Jackman, 1982). The whole-cell protein patterns of 102 strains were compared. These were designated group JK by the CDC or isolated in the UK between 1983 and 1985 and described as similar to that group. The relationship of group JK to other Corynebacterium spp. is the subject of a separate study to be published elsewhere.

\section{METHODS}

Strains. Corynebacterium strains and their sources are listed in Table 1.

Preparation of protein extracts. Strains were cultured on a medium of tryptone soya broth (Oxoid), $30 \mathrm{~g}$; yeast extract (Difco), $10 \mathrm{~g}$; agar, $12 \mathrm{~g}$ and $5 \mathrm{ml}$ Tween 80 per litre for $48 \mathrm{~h}$ at $37^{\circ} \mathrm{C}$. Cells $(0.1 \mathrm{~g})$ were harvested with a loop and lysed by incubation in $1 \mathrm{ml} 0 \cdot 1 \%(\mathrm{w} / \mathrm{v})$ lysozyme for $3 \mathrm{~h}$ at $37^{\circ} \mathrm{C}$. The lysate was heated at $100{ }^{\circ} \mathrm{C}$ in the sample treatment buffer of Laemmli (1970) for $10 \mathrm{~min}$ and centrifuged for $10 \mathrm{~min}$ at $10000 \mathrm{~g}$. The supernatant was stored at $-20^{\circ} \mathrm{C}$ before electrophoresis.

Electrophoresis. Samples were separated by SDS-PAGE in $10 \%(\mathrm{w} / \mathrm{v})$ polyacrylamide gels (Laemmli, 1970) and standardized by the method of Jackman (1985).

Analysis of patterns. Patterns were scanned with a densitometer (Joyce-Loebl, Chromoscan 3) fitted with a $530 \mathrm{~nm}$ filter and a $3.0 \times 0.1 \mathrm{~mm}$ slit aperture. Absorbance values were recorded at $0.2 \mathrm{~mm}$ intervals along the gel using a microcomputer (Sage IV, TDI Bristol, UK) interfaced with the densitometer. The patterns were corrected for gel-to-gel variation using a replicate bacterial sample (C454) run on each gel as a calibration pattern. Ten peaks were selected at approximately even intervals along the calibration pattern spanning a molecular mass range of 20

$†$ Present address: Division of Microbiology, Food Research Institute, Colney Lane, Norwich NR4 7UA, UK. 
Table 1. Corynebacterium sp. strains

\begin{tabular}{|c|c|c|c|}
\hline $\begin{array}{l}\text { Laboratory } \\
\text { no. }\end{array}$ & Source & $\begin{array}{l}\text { Laboratory } \\
\text { no. }\end{array}$ & Source \\
\hline $\begin{array}{l}\text { C9, C10, C21, C27, } \\
\text { C28, C29 }\end{array}$ & $\begin{array}{l}\text { NCTC A16/66, A17/66, } \\
\text { A9/73, A113/74, A136/74, } \\
\text { A137/74. Described in } \\
\text { Athalye et al. (1984, 1985). } \\
\text { C28 is NCTC } 11914 \text {. } \\
\text { L. Tomkins, University } \\
\text { Hospital, Seattle, Wash., } \\
\text { USA. Described in Athalye } \\
\text { et al. (1984, 1985); Stamm et }\end{array}$ & 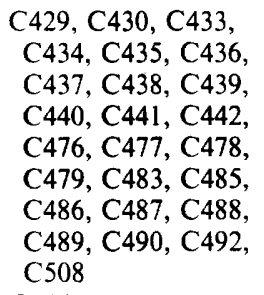 & $\begin{array}{l}\text { Royal Marsden Hospital, } \\
\text { London, UK. C428 is NCTC } \\
11917 \text {. C } 483 \text { is NCTC } 11915 \\
\text { and K411 in Kerry-Williams } \\
\text { \& Noble (1984). }\end{array}$ \\
\hline $\mathrm{C} 105, \mathrm{C} 204, \mathrm{C} 205$ & $\begin{array}{l}\text { al. (1979). } \\
\text { Royal Marsden Hospital, }\end{array}$ & C444 & $\begin{array}{l}\text { PHL, Leicester Royal } \\
\text { Infirmary, UK }\end{array}$ \\
\hline $\begin{array}{l}\mathrm{C} 226, \mathrm{C} 428 \\
\mathrm{C} 137\end{array}$ & $\begin{array}{l}\text { London, UK } \\
\text { University College Hospital, } \\
\text { London, UK }\end{array}$ & $\begin{array}{l}\text { C445, C446, C447, } \\
\text { C448, C449, C451, } \\
\text { C452, C453, C454, }\end{array}$ & $\begin{array}{l}\text { R. Weaver, CDC, Atlanta, } \\
\text { Ga., USA. Described in } \\
\text { Riley et al. (1979). C454 is }\end{array}$ \\
\hline C206, C207 & $\begin{array}{l}\text { St Paul's Hospital, London, } \\
\text { UK }\end{array}$ & $\begin{array}{l}\text { C455, C456, C } 457 \text {, } \\
\text { C } 458, \text { C } 459, \text { C } 461 \text {, }\end{array}$ & NCTC 11913. \\
\hline $\mathrm{C} 217$ & $\begin{array}{l}\text { Herts. and Essex Hospital, } \\
\text { Bishops Stortford, UK }\end{array}$ & $\begin{array}{l}\text { C462, C463, C464 } \\
\text { C467, C468, C469, }\end{array}$ & Walton Hospital, Liverpool, \\
\hline $\mathrm{C} 218, \mathrm{C} 225$ & $\begin{array}{l}\text { Lister Hospital, Stevenage, } \\
\text { UK }\end{array}$ & $\begin{array}{l}\text { C470, C471 } \\
\text { C472, C494, C495, }\end{array}$ & \\
\hline $\mathrm{C} 220, \mathrm{C} 419, \mathrm{C} 420$ & $\begin{array}{l}\text { Kings College Hospital, } \\
\text { London, UK }\end{array}$ & $\begin{array}{l}\text { C } 496, \text { C } 497, \text { C } 498 \\
\text { C } 499\end{array}$ & London, UK \\
\hline \multirow{2}{*}{$\begin{array}{l}\text { C221, C426, C506 } \\
\text { C222 }\end{array}$} & Bradford Royal Infirmary, UK & C473 & Department of Microbiology, \\
\hline & $\begin{array}{l}\text { RAF Institute of Pathology } \\
\text { and Tropical Medicine, } \\
\text { Aylesbury, UK }\end{array}$ & $\begin{array}{l}\text { C475, C493, C501, } \\
\text { C510 }\end{array}$ & $\begin{array}{l}\text { University of Bristol, UK } \\
\text { Southmead General Hospital, } \\
\text { Bristol, UK }\end{array}$ \\
\hline $\mathrm{C} 227$ & $\begin{array}{l}\text { North Devon District } \\
\text { Hospital, Barnstable, UK }\end{array}$ & C484 & $\begin{array}{l}\text { St Helier Hospital, Carshalton, } \\
\text { UK }\end{array}$ \\
\hline $\begin{array}{l}\text { C416, C417, C421, } \\
\text { C422 }\end{array}$ & $\begin{array}{l}\text { Mayday Hospital, Croydon, } \\
\text { UK }\end{array}$ & C502 & $\begin{array}{l}\text { London College of Surgeons, } \\
\text { UK }\end{array}$ \\
\hline \multirow[t]{3}{*}{$\mathrm{C} 424$} & $\begin{array}{l}\text { Northwick Park Hospital, } \\
\text { London, UK }\end{array}$ & $\begin{array}{l}\text { C504, C511, C512, } \\
\text { C513 }\end{array}$ & The London Hospital, UK \\
\hline & & C545 & $\begin{array}{l}\text { Isle of Thanet District } \\
\text { Hospital, Margate, UK }\end{array}$ \\
\hline & & $\mathrm{C} 507$ & $\begin{array}{l}\text { Withington Hospital, } \\
\text { Manchester, UK }\end{array}$ \\
\hline
\end{tabular}

to $100 \mathrm{kDa}$. The distances between each of the calibration peaks were measured on every gel and a single pattern was chosen to act as reference for the whole study. Then the corresponding sections of the bacterial patterns on each gel were corrected by expansion or contraction to the reference distances. The length was corrected by three point quadratic interpolation (Jackman et al., 1983).

The absorbance traces of the patterns were compared with the correlation coefficient and UPGMA clustering, as was found useful in previous studies (Jackman et al., 1983; Kersters \& De Ley, 1975). A computer program in Pascal to do these procedures is available from the corresponding author.

\section{RESULTS AND DISCUSSION}

Representative whole-cell protein patterns are shown in Fig. 1. The numerical comparison of the patterns is shown as a dendrogram in Fig. 2. All but nine of the 102 strains formed a single cluster linked at $>0.70$ correlation. The strains clustered at this level appeared to match most closely with a visual assessment of the electropherograms. Further taxonomic measures are required to confirm the classification obtained from protein patterns. The mean correlation between replicate samples run on each of the 12 gels used was 0.93 after correction for gel-to-gel variation as described in Methods. Since many of the strains had been identified only by their coryneform morphology and antibiotic resistance, the high level of homogeneity observed was remarkable, particularly in view of the diversity amongst both reference Corynebacterium spp. and isolates from human skin found in a previous study (Jackman, 1982). The level of similarity 

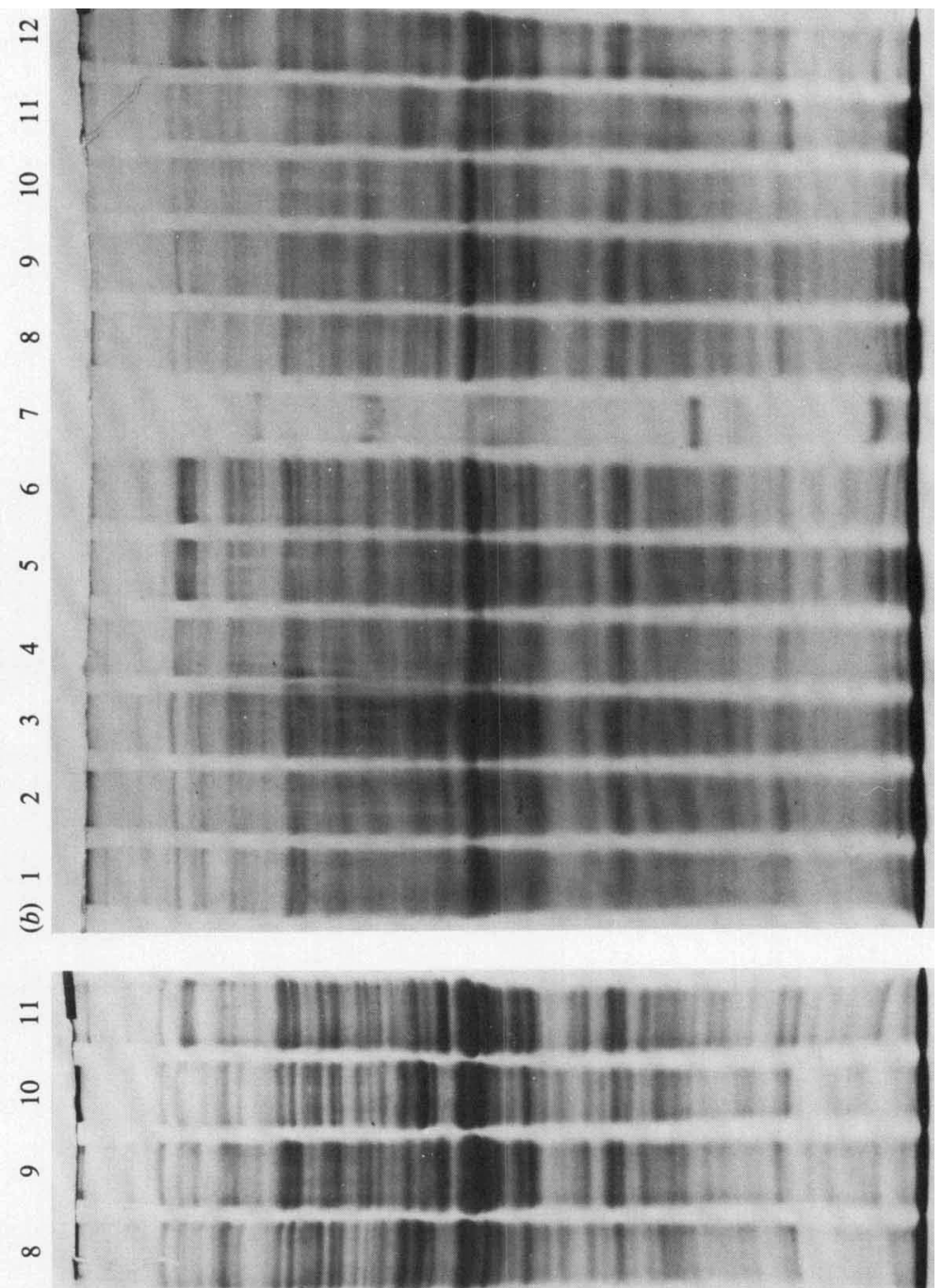

r

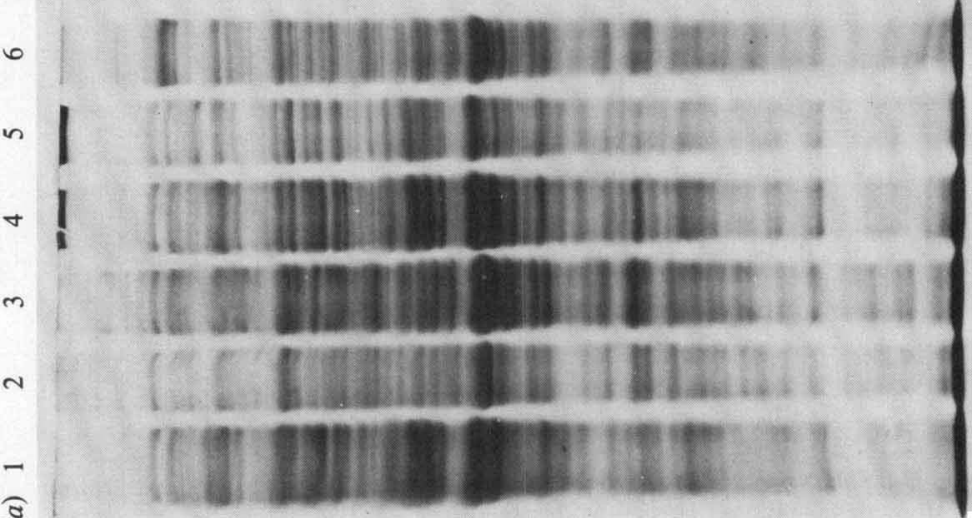



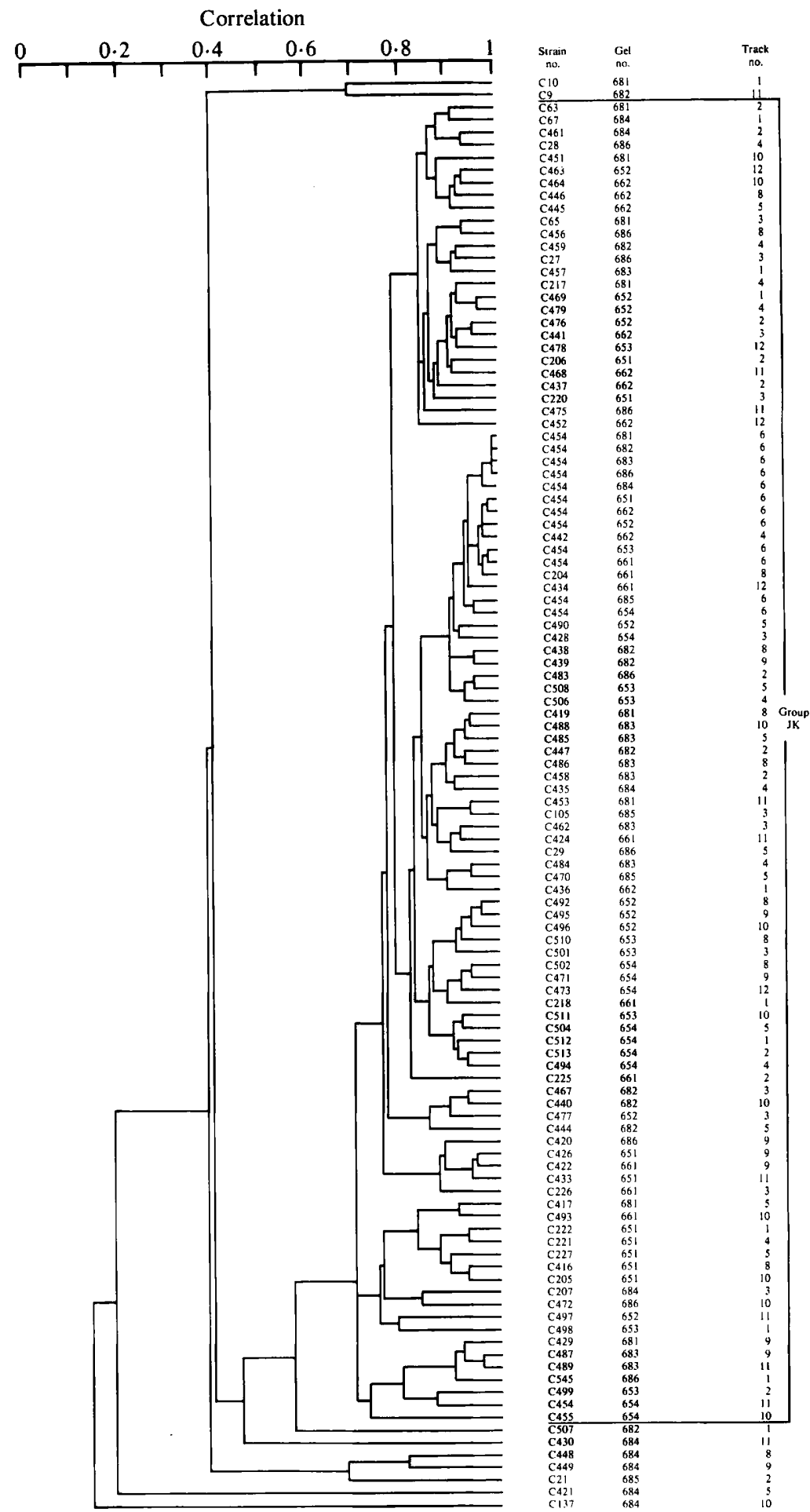

Fig. 2. Dendrogram of Corynebacterium group JK based on comparison of whole-cell protein patterns using the correlation coefficient and UPGMA clustering. 
among the group JK strains was similar to that between reference strains of $C$. diphtheriae (Jackman, 1982), which confirms the coherence of the group, as found by Riley et al. (1979). All group JK patterns were characterized by a prominent band of about $45 \mathrm{kDa}$; however, there was much fine strain variation particularly in the high molecular mass range of the gel. Some of these pattern variants formed subclusters in the dendrogram, e.g. a cluster of 11 strains (C417 to C498) linking at $>0.75$; however, other observable variants did not cluster. This may be due to an inherent weighting of the correlation coefficient towards the bigger features of the patterns. As far as could be ascertained, the observable strain variants showed no particular association with clinical source.

This study provides evidence that there are a considerable number of opportunistic infections recently detected in the UK which are associated with strains of the species described as Corynebacterium group JK by the CDC. The commonest sources of group JK isolates were blood $(45 \%)$, infected lines or shunts $(9 \%)$, urethra or urine $(7 \%)$, ulcers and abscesses $(4 \%)$ and heart $(3 \%)$. The commonest associated conditions were leukaemia $(16 \%)$ and renal dialysis $(9 \%)$. Twelve isolates were from the skin or vagina of cancer patients. The clinical picture of group JK as an opportunistic pathogen of immuno-compromised patients was confirmed in the UK, but with perhaps fewer cases of endocarditis than expected.

The support of this work by the MRC is gratefully acknowledged.

\section{REFERENCES}

Athalye, M., Noble, W. C., Mallet, A. I. \& MinNikin, D. E. (1984). Gas chromatography-mass spectrometry of mycolic acids as a tool in the identification of medically important coryneform bacteria. Journal of General Microbiology 130, 513-519.

Athalye, M., Noble, W. C. \& Minnikin, D. E. (1985). Analysis of cellular fatty acids by gas chromatography as a tool in the identification of medically important coryneform bacteria. Journal of Applied Bacteriology 58, 507-512.

JACKMAN, P. J. H. (1982). Classification of Corynebacterium species from axillary skin by numerical analysis of electrophoretic protein patterns. Journal of Medical Microbiology 15, 485-492.

JACKMAN, P. J. H. (1985). Bacterial taxonomy based on electrophoretic whole-cell protein patterns. In Chemical Methods in Bacterial Systematics, pp. 115128. Edited by M. Goodfellow \& D. Minnikin. London: Academic Press.

Jackman, P. J. H., Feltham, R. K. A. \& Sneath, P. H. A. (1983). A program in BASIC for numerical taxonomy of microorganisms based on electrophoretic protein patterns. Microbios Letters 23, 87-98.

KerRy-Williams, S. M. \& Noble, W. C. (1984).
Plasmid associated bacteriocin production in a $\mathbf{J K}$ type coryneform bacterium. FEMS Microbiology Letters 25, 179-182.

KERSTERS, K. \& De LEY, J. (1975). Identification and grouping of bacteria by numerical analysis of their electrophoretic protein patterns. Journal of General Microbiology 87, 333-342.

LAEMMLI, U. K. (1970). Cleavage of structural proteins during the assembly of the head of bacteriophage T4. Nature, London 227, 680-685.

OWEN, R. J. \& JACKMAN, P. J. H. (1982). The similarities between Pseudomonas paucimobilis and allied bacteria derived from analysis of deoxyribonucleic acids and electrophoretic protein patterns. Journal of General Microbiology 128, 2945-2954.

Riley, P. S., Hollis, D. G., UtTer, G. B., Weaver, R. E. \& BAKER, C. N. (1979). Characterisation and identification of 95 diptheroid (group JK) cultures isolated from clinical specimens. Journal of Clinical Microbiology 9, 418-424.

Stamm, 'W. E., Tomkins, L. S., Wagner, K. F., Counts, G. W., Donnall Thomas, E. \& Meyers, J. D. (1979). Infection due to Corynebacterium species in marrow transplant patients. Annals of Internal Medicine 91, 167-173. 